\title{
Horváth Miklós
}

\section{„Lehelyezett kõ..." \\ M. Szabó Miklós altábornagy, akadémikus életmûve DOI 10.17047/HADTUD.2021.31.1.108}

\section{Életrajz}

A tragikus hirtelenséggel elhunyt M. Szabó Miklós az MTA levelezõ tagjaként 2002-ben megfogalmazott bemutatkozó írásában ${ }^{1}$ nagyapai-apai „örökségének” tartotta a történelem és a földrajz iránti szeretetét. Gyermekkorában a történelemmel való ismerkedését segítette, tette lehetõvé a család több száz kötetes könyvtára.

1942-ben Tiszadorozsmán született. Az általános iskola befejezését követõen 1956-ban kezdete meg tanulmányait a II. Rákóczi Ferenc Katonai Középiskolában, majd az Egyesített Tiszti Iskola gépesített lövész szakának elvégzését követõen, 1964 szeptemberében hadnagyi rendfokozattal az egri 6. gépesített lövészezred szakaszparancsnokaként kezdte meg a hivatásos tiszti szolgálatot. Öt év csapatszolgálat után került a Kossuth Lajos Katonai Fõiskola állományába.

Oktatói munkája mellett 1972-ben jeles eredménnyel fejezte be a tanulmányait Zrínyi Miklós Katonai Akadémián, 1976-ban pedig elvégezte az Eötvös Lóránd Tudományegyetem Bölcsészettudományi Kar történelem szakát, ahol 1977-ben bölcsészdoktori címet szerzett.

A hivatásos katonai pályája legelején bekapcsolódott a Tudományos Ismeretterjesztõ Társulat munkájába. Az egyik nagy sikerû elõadását meghallgatva, a Zrínyi Miklós Katonai Akadémia Hadmûvészet-történet tanszékének vezetõje meghívta oktatónak. Ettõl az idõponttól kezdve öt éven keresztül az akadémia Hadmûvészet-történet tanszékének az oktatója, 1981-tõl tanszékvezetõ-helyettese, 1984-ig tanszékvezetõje volt. Kapcsolata a tanszékkel haláláig megmaradt. Az Akadémia parancsnokának társadalomtudományi helyettesévé 1984-ben nevezték ki.

\footnotetext{
Pázmány Péter Katolikus Egyetem, Bölcsészet- és Társadalomtudományi Kar - Pázmány

Péter Catholic University, Faculty of Humanities and Social Sciences; e-mail:

hmiklos@nsoft.hu; https://orcid.org/ 1

M. Szabó 2002, 212-213.
}

1981-ben védte meg a hadtudomány kandidátusa, 1987-ben a hadtudomány doktora címet.

1988-ban nevezték ki egyetemi tanárrá.

1989 és 1991 között a Zalka Máté (a késõbbi Bolyai János) Katonai Mûszaki Fõiskola, 1991-tõl 1996-ig a Zrínyi Miklós Katonai Akadémia Parancsnoka, majd 2011-ig az 
Akadémia átszervezését követõen létrejött Zrínyi Miklós Nemzetvédelmi Egyetem rektora, utóbb Rector Emeritusa, 2013-tól a Nemzeti Közszolgálati Egyetem Professor Emeritusa. ${ }^{1}$

A ZMKA parancsnokává történt kinevezését 1991-ben támogató javaslatban olvasható értékelés szerint M. Szabó Miklós „magasfokú szakmai felkészültséggel rendelkezik, munkáját példás szorgalommal, jó szervezõkészséggel és vezetõi tulajdonságokkal eredményesen végzi. [...] Megalapozott történelmi ismeretek bírtokában korszerû módszerekkel és eszközökkel - beosztása mellett - magas színvonalon oktatta a hadtörténelmet és a hadmûvészt történetét. Nagy gondot fordít a hallgatói állomány szakmai és pedagógiai felkészítésére, továbbképzésére. Az új iránt fogékony, lépést tart a fejlõdéssel. [...] Meglapozott tekintélyt és elismertséget vívott ki magának a szakterületéhez tartozó tudományos körökben. A TMB (Tudományos Minõsítõ Bizottság) Hadtudományi Szakbizottságának tagjaként jól segíti és irányítja a hadtudományi kutatómunkát, Folyamatosan figyelemmel kíséri a tudományterület nemzetközi eredményeit. [...] Magatartása fegyelmezett, példamutató. [...] Képességei, felkészültsége, fejlõdése, emberi tulajdonságai és vezetõi tapasztalatai az oktató-nevelõ és tudományos munka irányítása terén magasabb beosztás eredményes ellátására is alkalmassá teszik." ${ }^{2}$

1997. március 15-i hatállyal került szolgálati nyugállományba. Az egy évvel korábban készült szolgálati jellemzésébõl kiemelendõ: „A Zrínyi Miklós Katonai Akadémia parancsnoki munkáját magasfokú felkészültséggel, követelménytámasztással és eredményesen látja el. Elévülhetetlen érdemeket szerzett az egyetemi színvonalú képzés megteremtésében és az új szervezeti struktúra kialakításában."3

Jelentõs hazai és nemzetközi tudományos közéleti, valamint tudományszervezõ munkásságot fejtett ki. 1994-tõl többek között az MTA Közgyûlés doktori küldötte és a IX. Osztály Hadtudományi Bizottságának elnöke volt. 1990-tõl az elsõk között törte át diszciplínájának zártságát, és bekapcsolódott a nemzetközi hadtudományi, valamint katonai felsõoktatási életbe.

Kiemelkedõ tudományos munkásságával és a magyar katonai felsõoktatás megújításában játszott vezetõ szerepével hozzájárult a hazai hadtudomány fejlõdéséhez, valamint nemzetközi tekintélyének emeléséhez. ${ }^{4}$

2001-tõl az MTA levelezõ, 2007-tõl pedig a rendes tagja, katonai beosztásában végzett munkája elismeréseként 1990-ben kinevezték vezérõrnagynak.

Tudományos pályafutása során szerzõként 26 könyve és 15 könyvrészlete, 3 egyetemi tankönyve, több mint 93 tudományos folyóiratcikke, 12 konferencia közleménye, ebbõl idegen nyelven itthon és külföldön (például angol, német, francia, spanyol, görög, szlovák, cseh nyelven) mindösszesen 17 közleménye jelent meg, továbbá 6 könyvet szerkesztett. Élete végéig tartó tudományos aktivitásának fontos jellemzõje, hogy csak az elmúlt öt évben

\footnotetext{
${ }^{1}$ A Magyar Honvédség Parancsnokának 367/2021. MHP személyügyi parancsa a Magyar Honvédség halottjává nyilvánításról. 2021. március 12., a parancsot aláírta: Korom Ferenc vezérezredes.

${ }^{2}$ Szolgálati jellemzés - kinevezési javaslat - 1991. HM Hadtörténeti Intézet és Múzeum, Központi Irattár, Tiszti okmánygyûjtõ.

${ }^{3}$ Szolgálati jellemzés - 1996. - vezénylés, áthelyezés, megbízás. Uo.

${ }^{4}$ Akadémiai tagajánlások - 2001. Ajánlók: Mátyás Antal, Simai Mihály, Szentes Tamás. Magyar Tudomány 2000 45 (12): 93.
} 
szerzõként vagy társszerzõként 4 könyvét adták ki. Munkásságára, tudományos közleményeire közel 400 esetben hivatkoztak bel-, valamint 111-szer külföldön. ${ }^{5}$

A hivatásos katonai szolgálat elismeréseként, tudományos tevékenységéért kapott számos kitüntetése közül kiemelendõ a Zrínyi Miklós-díj (1995), a Magyar Köztársasági Érdemrend középkeresztje (1996) és a Magyar Köztársasági Érdemrend

Középkeresztje a csillaggal (katonai tagozat 2004). A Magyar Köztársaság elnöke 2006. május 21-i hatállyal elõléptette altábornaggyá.

Napjainkig helytálló Ács Tibor hadtörténész még 2009-ben, A Zrínyi Miklós Katonai Akadémia története 1961-1969 címû könyvet méltató írásában olvasható értékelése: „M. Szabó Miklós közel négy évtizedes kiemelkedõ tudományos kutatói tevékenysége mindenekelõtt a második világháború hadügyi változásai, a magyar katonai részvétel, a magyarországi hadmûveletek, a Magyar Királyi Honvéd Légierõ története és háborús alkalmazása feltárásával, feldolgozásával vált elismertté tudományszakának, a hadtudomány, a hadtörténet mértékadó hazai és nemzetközi körei elõtt. Tudósi hírnevéhez azonban jelentõsen hozzájárult az a tény is, hogy a magyar katonai felsõoktatás történetének egyik legkiválóbb kutatója. [...] Vezetõ szerepet játszott az elmúlt tizenhét esztendõben a magyar katonai felsõoktatás megújításában, a nemzetközi viszonylatban is szinte egyedülálló, az elmúlt években hazai felsõoktatási tanintézetek között is rangos helyet elfoglaló, Zrínyi Miklós Nemzetvédelmi Egyetem létrehozásában.

Rektori mûködése alatt a civil és az elõd katonai tanintézetek legjobb hagyományaiból és történelmi tanulságaiból merítve, korunk állandó oktatói és kutatói kihívásainak megfelelõ válaszokat keresve vált az egyetem korszerû felsõoktatási intézménnyé, a hazai hadtudományi kutatások központjává es a magyar és európai egyetemek, akadémiák elismert tagjává. [...]

M. Szabó Miklós nyugállományú altábornagy, az MTA rendes tagja, több mint másfél évtizeden át volt a magyar felsõoktatás, a hazai és az európai (a NATO) katonai felsõoktatás egyik megbecsült szereplõje."

Az alábbiakban kutatói, hadtörténészi munkásságának két legfontosabb területét próbálom számba venni.

\section{A magyar királyi légierõ története}

M. Szabó Miklós az oktató teendõk ellátásával párhuzamosan kezdte meg a légierõelmélettel, majd a Magyar Királyi Légierõ történetével kapcsolatos kutatásait. Kezdetben elsõsorban a második világháború magyarországi hadmûveleteit, a magyar légierõ technikai és szervezeti fejlõdését vizsgálta, de ezzel összefüggésben foglalkoznia kellet gazdasági, hadiipari, külkereskedelmi, szervezési kérdésekkel is. ${ }^{6}$

\footnotetext{
${ }^{5}$ Magyar Tudományos Mûvek Tára - M. Szabó Miklós:

https://m2.mtmt.hu/gui2/?type=authors\&mode=browse\&sel=10000408 (Utolsó letöltés: 2021. 05. 09.) 7 Ács 2009, 1424-1428.

${ }^{6}$ M. Szabó 2002, 212-213.
} 
A hazai repülést és a légierõ történetét feldolgozó kandidátusi értekezését 1981-ben maximális pontszámmal védte meg. Az 1982-ben megjelent munkában arra vállalkozott, hogy, mint írja „,a rendelkezésre álló rendkívül hiányos anyagú, s a szakemberek által is meglehetõsen mellõzött honvéd légierõ technikai és szervezeti fejlõdését felvázolva" hozzájáruljon egy teljes értékû monografikus feldolgozáshoz. Hármas célt maga elé tûzve bemutatta azokat a nézeteket, szellemi erõfeszítéseket, amelyek megalapozni, illetve a késõbbiekben továbbfejleszteni szándékozták a magyar légierõ létrehozását; a hazai termelést, a külföldi beszerzést; szándékai szerint megtisztítva minden túlzástól, illetve leértékeléstõl a valóságos technikai fejlõdést; a szervezeti fejlõdést, az ezzel kapcsolatos erõfeszítéseket, ezek eredményeit és kudarcait. ${ }^{7}$

1986-ban a Nagyváradi Sándorral és Winkler Lászlóval közösen jegyzett tanulmánykötetben a titkos, majd a nyílt légierõ megteremtésére, szervezésére és fejlesztésére irányuló törekvéseket, a Magyar Királyi Honvéd légierõ szervezeti fejlõdését, a repülõkötelékek harci alkalmazását tárta fel. ${ }^{8}$

A következõ évben e témakörben kiadott A Magyar Királyi Honvéd Légierõ a második világháborúban címû könyve ${ }^{9}$ bevezetõjében M. Szabó Miklós megállapítja: „Nehéz munkára vállalkozik az, aki a históriának közeli idõszakához nyúl vissza. A sebek még frissek, sok személyes emlék kapcsolódik hozzájuk. Különösen így van ez, ha a téma háborút is magában foglal. Válaszolni kell a mind gyakrabban megfogalmazott kérdésekre, mert azóta új nemzedék nõtt fel, amely nem élte át ezeket az eseményeket, de érdeklõdik utánuk, tisztán akarja látni apái tetteit, sorsát, és reális nemzeti önismereten alapuló öntudat nélkül nem építhetõ a jövõ. [...] A szerzõ erkölcsi kötelességének tartotta, hogy mindezekrõl véleményt is mondjon, de minden bizonnyal ezt teszik azok is, akik e bonyolult, ellentmondásos problémákkal foglalkozó, a második világháborús tragédia egy fejezetét bemutató könyvet átlapozzák." 10

M. Szabó Miklósnak az e témakörben folytatott kutatásait segítõ, de nem egyszer kritikával is illetõ Magyar Szárnyak szerkesztõje, Péterdi A. János szerint a munka lényegében összefoglalja a volt magyar királyi honvéd légierõ történetét, „ha sok tényi hibával is, mely talán nem is a szerzõ mulasztásából ered, mert hiszen a szerzõt alapos, lelkiismeretes kutatónak ismertük meg."13

A Magyar Szárnyak 1988-as számában Bakcsy Gergely a Könyvszemle ürügyén a hadtörténészekrõl és magunkról címû írásában M. Szabó Miklós könyve egyik nagy érdemének tartotta, ,hogy a repülõkkel, mint önálló fegyvernemmel foglalkozik, másik érdeme, hogy a feltüntetett felhasznált forrásmunkák zöme a Magyar Szárnyaktól származik.

\footnotetext{
${ }^{7}$ M. Szabó 1982, 7.

${ }^{8}$ Nagyváradi, M. Szabó, Winkler 1986.

${ }^{9}$ M. Szabó 1987.

${ }^{10}$ M. Szabó 1987, 7. A kötet alapját képezõ - kandidátusi értekezésként megvédett - kéziratot a szerzõ 1980-1981ben zárta. A könyv kiadásáig eltelt idõszakban kutatásai eredményeit a Hadtörténelmi Közleményekben több tanulmányban publikálta. Mint az a Kanadában rendszeresen megjelenõ Magyar Szárnyak címû folyóirat 1986-os számában olvasható, ezek közül „Az 1. repülõcsoport harcai 1942-ben a magyar források türkrében” címû „tárgyilagosságra törekvõ” cikkét a „hozzászólások lényegében örömmel és elismeréssel fogadták”. Magyar Szárnyak repülésügyi folyóirat (Kanada) 1986, 48. 13 Magyar Szárnyak 1988, 19.
} 
Ezzel a Magyar Szárnyakat az elismert forrásmunkák rangjára emelte, amit nekünk méltányolnunk kell, még akkor is, ha mû egyes részeivel nem értünk egyet. Amikor itt a többesszámot használom, teszem ezt azért, mert mû megjelenésének szinte elsõ percétõl az itthon élõ bajtársakban kiváltott elismerést vagy kritikai bírálatot összegezem." 11

M. Szabó Miklós a Magyar Szárnyak 1989-es száma Vitafórum rovatában mondott köszönetet a lap szerkesztõségének és szerzõinek, hogy az elmúlt években figyelemmel kísérték repüléstörténeti munkásságát, s többségükben reális, segítõkész észrevételekkel igyekezett támogatni történelemfeltáró erõfeszítéseit. „Õszintén vallom - írta -, hogy egyetértéseink és vitáink is egyaránt egyet kell, hogy szolgáljanak: a Magyar Királyi Honvéd Légierõk rövid, de mozgalmas történetének minél alaposabb, sokoldalúbb és objektívebb bemutatását."

Majd Ghyczy Tihamér korábbi véleményére - „Szabó Miklós cikkén keresztül az otthoni magyarok - elsõsorban persze a repülõk - békülõ jobbot nyújtanak felénk ... Mi magyar repülõk, akik híresek voltunk összetartó bajtársiasságunkról, nem mutatnánk jó példát és nem segíthetnénk õket ebbeli igyekezetükben? Nem nyújthatnánk mi is békülõ jobbunkat hazafelé?” 12 - reagálva írja: „Szerintem ez a kölcsönös bizalomra, megértésre törekvés szolgálhatja igazán a közös érdekeket.” Ide kívánkozik még Péterdi A. János szerkesztõ a Magyar Szárnyak hasábjain folyó vitát záró véleménye: „Úgy gondolom, hogy nekünk adott válaszában [M. Szabó Miklós] õszinte, nyílt igyekezettel fáradozik a köztünk lévõ véleménykülönbségek lehetõség szerinti csökkentésén. [...] teljes mértékben elismerjük fáradhatatlan és értékes munkásságát, s mi azon vagyunk, hogy - különbségeink ellenére békésen együttmûködhessünk a Magyar Királyi Honvéd Légierõ történetének tárgyilagos megírásában." 13

A témakörben tovább folytatott kutatásainak eredményeit M. Szabó Miklós az 1999-ben és 2008-ban megjelent könyvekben foglalta össze. A magyar légierõ megszületésének 60. évfordulója alkalmából megjelent A Magyar Királyi Honvéd Légierõ elméleti-technikaiszervezeti fejlõdése és háborús alkalmazása 1938-1945 címû kötet elõszavában olvasható: „A Magyar Királyi Honvédség eme fegyverneme nyílt mûködésének szûk hét esztendeje alatt bár elkövetett sok hibát, a fejlesztésével kapcsolatos rendkívüli erõfeszítések, a háború alatti egyéni tevékenységek és a honi légvédelem terén bizonyított hõsies helytállásuk, önfeláldozásuk ... megkövetelik” e könyv megírását. „Legyen fõhajtás ez a könyv a légierõ mindazon tagjainak emléke elõtt, akik a Haza vélt vagy valós védelmében szakértelmükkel, hazaszeretetükkel megsokszorozták a Magyar Királyi Honvéd Légierõ teljesítõképességét. [...] Ugyanakkor ajánlom könyvemet azok figyelmébe is, akik napjainkban foglalkoznak, »küzdenek-kínlódnak« a Magyar Honvédség anyagi-technikai-szervezeti fejlesztésével: ne kövessenek el hasonló hibákat! Az itt vázolt múlt sok tekintetben kísért!"14

A 2008-ban megjelent Politika - gazdaság - légi fegyverkezés Európában az 1920-30as években címû munkájában a légi háború - elsõsorban Douhet - elmélete kialakulásának

\footnotetext{
${ }^{11}$ Magyar Szárnyak 1988, 29-31.

${ }^{12}$ Magyar Szárnyak 1986, 104.

${ }^{13}$ Magyar Szárnyak 1989, 119., 122.

${ }^{14}$ M. Szabó 1999, 5.
} 
gazdasági-politikai indítékait vizsgálta, azt, hogy „miért éppen Olaszországban született meg e koncepció, illetve a versailles-i békeszerzõdés által katonailag korlátozott, de a szövetségesek érdekellentéteit és forradalmaktól való rettegését ügyesen kihasználó Németország - valamint a többi hatalom - milyen mértékben használta fel a háborús elõkészületeiben Douhet tanításait?" 15

A Szabó Józseffel, a téma kiváló szakértõjével együtt ugyancsak 2008-ban napvilágot látott A magyar katonai repülés története 1938-2008 címû kötetben a magyar katonai repülés nyolc évtizede eseményeinek feldolgozása során elsõsorban a szervezeti fejlesztés, a harckészültség magas szinten tartása, a repülõkiképzés bemutatására helyezték a hangsúlyt. „Munkánk során célul tûztük ki - olvasható a mû elõszavában -, hogy az olvasó megismerje a haderõ fejlõdéstörténetét, az elsõ és második világháború alatti repülõtevékenységeket, valamint az 1945 utáni újrakezdés nehézségeit, a mennyiségi fejlesztés, majd csökkentés idõszakát; az 1956-os forradalom és szabadságharc alatti, annak leverésétõl a rendszerváltásig, majd napjainkig a magyar katonai repülés terén történt fontosabb eseményeket. Igyekszünk érzékeltetni a sugárhajtású, majd szuperszonikus repülõtechnika, helikoptertechnika megjelenésének és tömeges alkalmazásának problémáit, a csapatrepülõk létrejöttének, alkalmazásának szükségszerûségét, a szárazföldi csapatok érdekében végzett tevékenységét. [...] Történeti áttekintésünkben kötelességünknek éreztük, hogy emléket állítsunk mindazoknak a hajózó és más beosztású repülõkatonáknak, akik a háborúban, majd az 1945-tõl napjainkig eltelt idõszakban repülési feladataik végrehajtása közben - akár saját hibájukból, akár szolgálattal együtt járó, rajtuk kívülálló kedvezõtlen körülmények folytán a legdrágábbat, az életüket áldozták a haza légterének megvédéséért. Tisztelettel és nagy részvéttel hajtunk fejet emlékük elõtt." 16

\section{A magyar katonai felsõoktatás története}

„Rektorként és mint a Nemzetvédelmi Egyetem létrejöttének egyik irányítója, az új intézmény megszilárdításának-továbbfejlesztésének elsõ számú felelõse, a múltból merítve »erõt « próbálom felvázolni a magyar nemzetvédelmi felsõoktatás közeljövõjét.

Ezért ezekben az években a második világháború utáni magyar katonai felsõoktatás történetét kutatva, tudományos alapossággal feldolgozva törekszem bemutatni az elmúlt, közel ötven évben megtett hatalmas utat, miközben igyekszem levonni a ma is hasznosítható, alapvetõ következtetéseket. Ezt követõen részben a történelmi tapasztalatok, részben - s leginkább - a jelen, illetve a belátható közeljövõ egyre növekvõ igényei alapján megkísérlem meghatározni a Nemzetvédelmi Egyetem továbbfejlesztésének fõ irányait, azok tartalmát kb. 2010-ig.” - olvasható a korábban már idézett „bemutatkozó írásában”. ${ }^{17}$

A katonai felsõoktatás története témakörben írt elsõ - az 1947-1956 közötti idõszakot vizsgáló - kötetrõl (A magyar katonai felsõoktatás története 1947-1956) a szakmai kritika azt állapította meg: „A most megjelent kötetben magasra tette a mércét szerzõ,

\footnotetext{
${ }^{15}$ M. Szabó 2008a.

${ }^{16}$ Szabó, M. Szabó 2008, 5.

${ }^{17}$ M. Szabó 2002, 212-213.
} 
dokumentumértékû alapos munkával gazdagította a szakirodalmat. [...] Ez az a helyzet, amikor a történészi kvalitások más az elsõ oldalakon szembetûnõen elénk tárulnak és világosan megítélhetõk. [...] A könyv jelentõs érdeme, hogy kétségtelenné teszi - bemutatja -, hogy a korabeli Magyarországon a Zrínyi Akadémia és jogelõd szervezetei a katonai felsõoktatás tekintéllyel és egyedülálló autentikussággal rendelkezõ intézménye volt és maradt." ${ }^{18}$ M. Szabó Miklós ezt a kötetet és több késõbbi munkáját is a katonai felsõoktatás mindenkori robotosainak ajánlotta. ${ }^{19}$

A 2007-ben megjelent folytatás utószavában M. Szabó Miklós az 1955 és 1960 között tevékenykedõ három parancsnok (Mátékovics Endre vezérõrnagy, Márton András ezredes és Csémi Károly tábornok) elévülhetetlen érdemének tartotta, hogy „rendkívüli politikaigazdasági viszonyok között megõrizte a katonai felsõoktatás alapintézményét, majd egyesítését követõen mint egyetlen katonai akadémiáját az egyáltalán lehetséges ütemben mind szervezetileg, mind tartalmilag korszerûsítve képessé tett az 1960/70-es években végrehajtandó - már valóban - megreformálásra."

A Márton Andrásról leírtakat olvasva M. Szabó Miklós emberségérõl és értékrendjérõl kaphatunk árnyaltabb képet: Márton András ezredes, akit a nagykõrösi református tanítóképzõben magába szívott nép- és hazaszeretete, a parancsnoktársai többségénél összehasonlíthatatlanul magasabb általános mûveltsége, kemény katonássága üstökösként lökött elõre a pályáján, alig 3 év alatt eljutva az ezredes rendfokozatig, majd újabb 4 esztendõt követõen az akadémiaparancsnok-helyettesi beosztáshoz. [Mint 1956. szeptember 22-én kinevezett parancsnokot] „1956. október 23-tól csak az a cél vezérelte, hogy az akadémiát a törvényes kormányzat parancsainak (ha lett volna ilyen!) szellemében vezetve-mûködtetve, a személyi állomány életét maximálisan megkímélve, a katonai és »népi« vagyont minél jobban megõrizve, a fegyelmet fenntartva, ha kellett a szovjet szövetséges katonákat és a magyar tisztek szovjet állampolgárságú feleségeit mentve, ha kellett a megszálló csapatokkal szemben a magyar katonai becsületet - a lehetõség határain belül - megõrizve, teljesítse parancsnoki kötelességét. A történelem - legalábbis az azt megjelenítõ hatalom hálátlannak bizonyult: a már kész tábornoki kinevezését visszavonva, 10 éves börtönre ítélve, kettétörte katonai pályáját, majd amnesztiával történt szabadulását követõen is megbélyegzettként kezelte." 20

Az e könyv kapcsán is elismerõ véleményt megfogalmazó Kolozsvári Sándor „,a résztvevõ, az érintett hitelességével” állapítja meg: ,igen jó könyv, tartalmilag korrekt és a figyelmes olvasó a kor atmoszféráját, az akadémia adott idõszakban kialakult hangulatát is »kiolvashatja« a kötetbõl. Az akkori idõket a helyszínen megélt legigényesebb érdeklõdõ is nosztalgiát érezhet, bár bizonyosan nem ez volt a szerzõ célja. Olyan összefoglaló, sallangmentes mû, amely évtizedek múltán is reális képet fest azokról az évekrõl és személyiségekrõl, akiket anno »helyzetbe hozott« a kiszámíthatatlan katonasors. Az eddig megjelent két kötet logikájából következhet annak feltételezése, hogy a »történet«

\footnotetext{
${ }^{18}$ Kolozsvári 2005, 42-43.

${ }^{19}$ M. Szabó 2004.

${ }^{20}$ M. Szabó 2007, 249-250.
} 
folytatódik, hasznos szolgálatot téve ezzel a múlt - a múltunk - objektív és reális bemutatásának. Mi, a múlt emberei ebben vagyunk érdekeltek." ${ }^{21}$

A történet már 2008-ban folytatódott. A Zrínyi Miklós Katonai Akadémia 1961 és 1969 közötti idõszakával foglalkozó újabb kötetet - és a mû 2010-es folytatását is - M. Szabó Miklós a szûkebb és tágabb családjának ajánlotta, ,akik valamilyen szinten és módon megszenvedték az akadémiához való kötõdésemet/kötõdésüket!” A szerzõ értékelése szerint a vizsgált korszaknak, „ennek a hullámzó hidegháborús periódusnak »köszönhetõen« a Magyar Néphadsereg soha nem tapasztalt fejlõdésnek indult [...] A hol feszültebb, hol enyhébb nemzetközi helyzet, a mind konszolidáltabb belpolitika, az ún. hadügyi forradalom parancsolóan írta elõ, illetve tette lehetõvé a katonai felsõoktatás lényeges korszerûsítésének megalapozását. [...] E könyv fejezetein elõrehaladva nyomon követhetjük azokat a lépéseket, amelyek fokozatosan teremtettek új, magas mûveltségû és szakismeretû, mind nagyobb számban több diplomával és tudományos fokozattal rendelkezõ tanári kart. Erre támaszkodva ki lehetett alakítani az akadémia új szervezetét, meg lehetett teremteni a perspektivikus célok megvalósításának alapjait, amelyekre építve az 1970-es években elindulhatott a Zrínyi Miklós Katonai Akadémia a folyamatos és mind nagyobb léptékû korszerûsítés útján."22

Ács Tibor - a már idézett ismertetõjében - úgy fogalmazott, hogy az „érdeklõdõ olvasó plasztikus és újszerû életképeket ismer meg a múlt század 60-as évtizedének katonai akadémiája zárt, sok vonatkozásban »Titkos!« minõsítésû mindennapjairól. A szerzõ mûvében egyértelmûen a hadtörténetírásnak azt a szakmai irányzatát képviseli, amely a téma feldolgozásakor mindig vizsgálja a korabeli politikailag és katonailag megosztott világ és szövetségi rendszerek problémakörét. A katonai tanintézet kérdéseinek felvetésekor nem mulasztja el a nemzetközi és hazai társadalmi, gazdasági es politikai, kulturális és tudományos, biztonsági és katonai állapotokba, viszonyokba, változásokba ágyazott alapos történeti elemzést. A kútfõk kritikus kezelésével, objektív szemléletû feldolgozásával érzékelteti a hazai katonai felsõoktatás sokszínû folyamatait és erõfeszítéseit, a hiányosságokat, a félmegoldásokat és a szakmai alulteljesítéseket."26

M. Szabó Miklós - mint ezt a sorozat következõ, az 1970 és 1979 közötti korszak tudományos kutatásainak eredményeit összegzõ részében is teszi, gyakran megfogalmaz kritikai észrevételeket. „Bár tovább folytatódott a Varsói Szerzõdés mûködésének korszerûsítési folyamata, de ez inkább az egységesítést szolgáló parancsok és szabályzatok tömeges kiadásában, a Magyar Néphadseregben történõ hatályba léptetésében fejezõdött ki, s nem - az elõzõ évtizedre jellemzõ - szervezeti tökéletesítéséért folytatott permanens küzdelemben. [Ebben az idõszakban] valódi felsõoktatási reformfolyamat zajlott a tanintézetben. [...] Mint e könyvbõl is kitûnik mind a tanári kar, mind a hallgatók minõségi mutatói lényeges fejlõdést mutattak a korábbi évekhez viszonyítva.”23

Akik ismerik Szabó Miklós korábbi, e témában nyilvánosságot kapott köteteit azok számára szembeszökõ a kontinuitás, a tények egymásra épülése. nem lehet nem észrevenni

\footnotetext{
${ }^{21}$ Kolozsvári 2007, 218.

${ }^{22}$ M. Szabó 2008b, 453-454. 26

Ács 2009, 1425.

${ }^{23}$ M. Szabó 2010, 273.
} 
azt a típusú belsõ egyensúlyt, amely a történész kutató igazi vénájára utal. „Nincsnek ún. kedvenc témák (vagy személyiségek), nem minõsít, csupán tényeket közöl, de mégis kiolvasható, mit tart értéknek, megõrzendõnek a jövõre nézve - írja Kolozsvári Sándor -. Hiszem és remélem. hogy a következõ évtized története már a szerzõ laptopjában várja a nyomdába adást, amely meggyõzõen fogja bizonyítani, hogy ennek az évtizednek a tanári állománya meghatározó módon járult hozzá az intézmény »beemeléséhez« (ahogyan a szerzõ találóan megfogalmazta a 272. oldalon) a magyar egyetemek közösségébe."24

Talán ezért is ajánlotta a 2011-ben megjelent következõ részt M. Szabó Miklós „mindazoknak, akik megalapozták a Nemzetvédelmi Egyetemet!” Az 1989-ig terjedõ idõszak történéseit elemezve végsõ következtetésként fogalmazta meg, hogy a „két akadémiaparancsnok [dr. Lantódi József vezérõrnagy, dr. Simon Sándor altábornagy] és a teljes személyi állomány maximális odaadásának köszönhetõen - a folyamatos korszerûsítések eredményeként - a Zrínyi Miklós Katonai Akadémia minden megrázkódtatást elkerülve teremtette meg a rendszerváltást követõ viszonyok közötti töretlen továbbmûködés, a NATO-akadémiák közösségének egyenrangú tagjává válás, illetve a Nemzetvédelmi Egyetemmé váló átalakulás feltételeit". ${ }^{25}$

M. Szabó ötödik könyve a Zrínyi Miklós Katonai Akadémia 80-as évekbeli történetét dolgozza fel a korábbi könyveiben megszokott módszertannal és objektivitással. Az errõl írott recenzióban Szenes Zoltán kiemeli, „hogy napjaink [2011] katonai felsõoktatási történései különleges olvasatot adnak a könyvnek, hiszen az olvasó óhatatlanul azt keresi, hogy mindazon hajtóerõk, módszerek és eljárások, amelyet a 80-as években a ZMKA a Honvédelmi Minisztériumtól kapott, hogyan fognak megvalósulni egy civil tárca által irányított és felügyelt rendszerben. [...] Szabó tábornok könyve éppen azt dokumentálja meggyõzõen, hogy a ZMKA nyolcvanas évekbeli sikerei a haderõn belül elfoglalt helyzetébõl származnak, mindent, amit elért, a honvédség részként érte el."26

Az egyetemmé válás 1990-1996 közötti idõszakának történetét tárgyaló ,hatodik kötetet” M. Szabó Miklós Oroszi Antal nyá. ezredessel közösen készítette. Mivel a korszak nagyobbik részében Szabó Miklós az Akadémia parancsnokaként funkcionált, és ezeket az éveket nehezen tudta volna objektíven, mintegy a „kívülálló szemével” vizsgálni, ezért az elsõ három fejezetet õ, a többi öt fejezetet Oroszi Antal jegyzi.

A könyvet a szerzõk Borsits László altábornagynak, vezérkari fõnöknek és a ZMKA személyi állományának ajánlották, ,akik erõs »ellenszelet« leküzdve - az itt bemutatott halatlan erõfeszítéseikkel - létrehozták a korábban soha és sehol sem volt Nemzetvédelmi Egyetemet".

2012 júniusában a szerzõk munkájukat az alábbi sorokkal zárták: „Feltárultak azok a kezdeményezések, majd eredmények, amelyek az egyre romló anyagi-gazdasági viszonyok, majd az idõszak utolsó szakaszában mind jobban érzékelhetõ emberi-egzisztenciális problémák ellenére 1996 õszére megteremtették a - soha és sehol nem volt! - nemzetvédelmi egyetem létrejöttének feltételeit. [...] Nem [a személyi állományon] múlott, hogy e korszerû,

\footnotetext{
${ }^{24}$ Kolozsvári 2010, 60-61.

${ }^{25}$ M. Szabó 2011.

${ }^{26}$ Szenes 2011, 134.
} 
mind hazánkban, mind külföldön nagy elismertséget kivívó magyar katonai intézménynek csak negyed századot adott a történelem!"27

Resperger István „hatodik könyv” által ihletett széljegyzeteibõl ide kívánkozik, hogy „,a recenzált mû egy nagyon értékes könyv. Értékes abban a tekintetben, hogy két történész végre feldolgozta és papírra vetette a Zrínyi Miklós Katonai Akadémia Zrínyi Miklós Nemzetvédelmi Egyetemmé válásának történetét. Roppant értékes a mû azért is, mert a belsõ folyamatokat megélõ, azokban mélyen érintett személyek láttatják az eseményeket; és kiemelten értékes azért, mert a "Zrínyin« történteket a biztonságpolitikai és katonadiplomáciai események elemzésével és magyarázatával fûszerezve ábrázolják. [...] A szerzõket nyilván nyomasztotta a krónikások felelõssége, az, hogy felül emelkedni a személyes érintettségen, a számtalan át nem aludt éjszakán, az intézmény jövõjével kapcsolatos sok aggódáson..."28

M. Szabó Miklós a Volt egyszer egy egyetem 1996-2007 - Rektor a tûzvonalban címû könyvét 2014-ben ezekkel a gondolatokkal nyújtotta át a Tisztelt Olvasóknak: „Ilyen lehetõségem az életben nem volt: hitvesi kezdeményezésre morzsolgathatom - remélem hasznosan - a nyugdíjas napjaimat! Ugyanakkor, bár továbbra is törekszem a történészi becsület megkövetelte maximális objektivitásra, de kérem - adott esetben - emlékezzenek az alcím második felére is: »... szubjektív emlékek«. [...] Így talán sok egykori odaadó munkatársamnak is emléket tudok állítani, akik hatalmas személyes áldozatokat hozva teremtették meg, fejlesztették tovább a Nemzetvédelmi Egyetemet, míg néhányan tönkre nem tették, majd ismét mások fel nem számolták." A kötetét a szerzõ mindazoknak is ajánlotta: „akikkel felépítettük ezt a soha, sehol nem volt tanintézetet, s akiket évek múltán méltatlanul eltávolítottak onnan."

M. Szabó Miklós szerzõi önvallomása szerint esze ágában „sem volt megírni a Zrínyi Miklós Nemzetvédelmi Egyetem [1996-2007 közötti] történetét, hiszen óhatatlanul keveredhetnek bele szubjektív meglátások”. Ám a talpraesett feleség felismerte, hogy ezt „,.. neked kell megírnod, az átélõ-megélõ résztvevõnek - ha évekre az asztalfióknak is! - mert a legtehetségesebb kutató sem olvashat ki mindent az iratokból. Az egyetemmel kapcsolatos személyes emlékeket is közkinccsé kell tenned!”33

A korábbi szerzõtárs, Oroszi Antal e könyv kapcsán 2015-ben papírra vetett értékelése szerint a Magyar Tudományos Akadémia egyetlen katona rendes tagja, az általa 1996 és 2007 között vezetett Zrínyi Miklós Nemzetvédelmi Egyetem rektori korszakának feldolgozásakor a „nála megszokott alapossággal kezeli az objektív tényeket. [...] Az alkotásban jól érzékelhetõ a felelõsség a közösségért, az intézmény rendeltetéséért és küldetéséért. A szerzõ [M. Szabó Miklós] nagy tisztelettel emlékezik odaadó munkatársaira, akik osztoztak a felelõsségben. [...] Az Olvasó érzékelheti, hogy a Zrínyi Miklós Nemzetvédelmi Egyetem rektora és munkatársai, a tanári kar, az ellátó és kiszolgáló állomány milyen áldozatos, sokszor éjt nappallá tevõ erõfeszítésekkel építette fel Magyarország egyetlen katonai egyetemét. És azt is, hogy a különbözõ, sokszor mondvacsinált, személyes intrikáktól sem

\footnotetext{
${ }^{27}$ M. Szabó, Oroszi 2012, 281.

${ }^{28}$ Resperger 2013, 63-64. 33
}

M. Szabó 2014, 5-6. 
mentes gondoktól és problémáktól sem mentesen felfelé ívelõ, jelentõs eredményeket és sok sikert hozó tanintézet történetét tartja a kezében."

A 2007. március 13-án megtartott ünnepi állománygyûlésen M. Szabó Miklós az egyetem leköszönõ rektora - hivatkozva református lelkipásztor nagyapja sírfeliratára ezekkel a szavakkal búcsúzott: »ama nemes harcot megharcoltam, a futásomat - idõnként vesszõfutásomat - elvégeztem, az egyetemet megtartottuk! « Ezzel lezárult - írja Oroszi Antal - a rektor életének legfontosabb szakasza, annak egyik értelme..."29

Életének új szakaszában M. Szabó Miklós egy percre sem megpihenve folytatta a tudományos alapkutatásokat, amelyek eredményeit a katonai fõiskolák történetét bemutató kötetekben Fekete Istvánnal és Fekete Lászlóval tette közkinccsé. A Kossuth Lajos Katonai Fõiskola majd 30 éves múltját vizsgálva és értékelve - mintegy a mû lezárásaként - állapította meg: „A nemzetközi helyzetben periodikusan bekövetkezõ hidegháborús hullámok a legkorszerûbb fegyverek és harceszközök tömegeit adták a katonák kezébe: a társadalom nem kis anyagi áldozata ás az idõnként háborús veszély a magyar haderõt története legkorszerûbb hadseregévé fejlesztette. Nos, az ezt kezelni, a legoptimálisabban alkalmazni, kiszolgálni képes fiatal tiszti generációk felkészítésében és a kiképzésében a Kossuth Lajos Katonai Fõiskola játszotta a döntõ szerepet. Mint láttuk, lépésrõl lépesre egyre kiválóbb tiszteket adtak a csapatoknak, ugyanakkor a pálya nem kellõ vonzása, a szorító alegységparancsnokhiány és a kapkodó, átgondolatlan felsõ szintû döntések, törést, sõt visszalépést is elõidéztek. Ennek ellenére, a szolgálatba lépett tisztek egyre jobban megfeleletek az új követelményeknek, s egy részük - a természetes kiválasztódás következtében - folyamatosan vált a Magyar Néphadsereg, majd a Honvédség mind magasabb szintû vezetõjévé.”30

A Fekete Istvánnal jegyzett újabb könyvvel - A katonai repülõszakember képzés Szolnokon. 1967-1996 - a szerzõk mindazok elõtt tisztelegtek, akik létrehozták és mûködtették a magyar tisztképzés e fontos intézményét.

Harmadikként ebben az évben jelent meg a Fekete Lászlóval közösen írt, A Katonai Mûszaki Fõiskola 1967-1999 közötti történetét ismertetõ kötet. ${ }^{31}$

„A Mór megtette a kötelességét, a Mór mehet...” mottóval bocsátotta útjára 2019-ben M. Szabó Miklós a Karikás Frigyes Katonai Kollégium története 1969-1991 címû mûvét. Ebben a szerzõ annak az intézménynek állított emléket, amely mint írja: „A magyar hadtörténelem legkorszerûbb haditechnikájával felszerelt hadereje mûködtetése elõfeltételeinek megteremtésében, biztosításában a Zrínyi Miklós Katonai Akadémia és a három katonai fõiskola mellett oroszlánrészt vállalt - egy speciális területen. [...] Minden olyat magára kellett vállalnia, ami a fent említett katonai felsõoktatási intézményeknek nem volt a rendeltetése, mint pl. a hazai egyetemeken és fõiskolákon megszerezhetõ speciális képzettség; a külföldi katonai akadémiákon és fõiskolákon a legkorszerûbb új eszközök, rakétatechnikák megismerése, üzemeltetésükre való magas szintû felkészülés; a legkorszerûbb katonaorvosi jártasságok elsajátítása stb. feltételeinek, kereteinek a biztosítása."

\footnotetext{
${ }^{29}$ Oroszi 2015, 172-173., 183.

${ }^{30}$ M. Szabó 2017.

${ }^{31}$ Fekete, M. Szabó 2017.
} 
Mint minden esetben, a személyes véleményének e kötetben is hangot adva, meggyõzõdöttséggel vallotta: ,a kollégium vezetése és munkatársai - ha nem is hibáktól mentesen, de összességében magas színvonalon megoldották, teljesítették is ezt a küldetést."

„Sajnos - olvasható néhány bekezdéssel késõbb - az életnek, így a rendszerváltozásának is a túlnyomó többségben pozitív következményei mellett voltak negatív hatásai, pl. sok tehetséges tiszt és tisztjelölt pályájára, amit talán lehetett volna hozzáértõbben, higgadtabban. politikamentesebben, összességében humánusabban kezelni. De sajnos ez már a jóvátehetetlen múlt!”

M. Szabó Miklós akadémikus utolsóként megjelent kötete végén - visszatekintve tudományos életének jelentõsebbnek tartott eseményeire - vetette papírra hadtörténészi tevékenységét értékelõ, összegzõ gondolatait: „Sok széprõl, felemelõ eredményrõl számolhattam be, amiket esetenként negatívumok is »tarkítottak«. Mégis, a végén minden esetben jó érzéssel ütöttem le az utolsó billentyût. E könyv esetében - sajnos - ez nem mondható el! Az utolsó oldalak - nem a kollégiumnak felróhatóan, az õ munkájukért (idõnként tûzoltásukért!) köszönet jár! - nagyon szomorúvá, elkeseredetté tettek. Így, az Olvasónak csak a reményemet üzenhetem - Petõfi

Sándort segítségül hívva -, miszerint: Más... [írásom]... majd több lesz és vidám.” 32

$$
* * *
$$

M. Szabó Miklós akadémikus, tábornok, professzor hadtörténész tragikus hirtelenséggel megszakadt élete, eredményekben és sikerekben gazdag munkásságának néhány fontosabb eseményét, állomását felidézõ írásomat egy 2017-ben megjelent munkából átvett Antoine de Saint-Exupéry-idézettel zárom: „Embernek lenni pontosan annyit jelent, mint felelõsnek lenni, érezni, hogy a kõvel, amelyet lehelyez, a világot építi tovább."33

FELHASZNÁLT IRODALOM

Ács Tibor 2009. Katonai felsõoktatás a múlt század második felében. A Zrínyi Miklós Katonai Akadémia története 1961-1969. (Könyvismertetés) Magyar Tudomány 55 (11): 1424-1428.

Akadémiai tagajánlások - 2001. Ajánlók: Mátyás Antal, Simai Mihály, Szentes Tamás. Magyar Tudomány 200045 (12): 93.

Fekete László, M. Szabó Miklós 2017. A Katonai Mûszaki Fõiskola története 1967-1999. Budapest: Zrínyi Kiadó.

Kolozsvári Sándor 2005. Recenzió helyett - M. Szabó Miklós - A magyar katonai felsõoktatás története 19471956. (Zrínyi Kiadó, 2004.) Nemzetvédelmi Egyetemi Fórum 2005, 42-43.

Kolozsvári Sándor 2007. Gondolatok M. Szabó Miklós „A Zrínyi Miklós Katonai története 1955-1960” címû könyvérõl. Társadalom és Honvédelem 2007, 218.

Kolozsvári Sándor nyá. ezredes 2010. A Zrínyi Miklós Katonai Akadémia története 1970-1979. (Zrínyi Kiadó, Budapest, 2010) címû könyvérõl. Honvédségi Szemle 2010 (5): 60-61.

Nagyváradi Sándor, M. Szabó Miklós, Winkler László 1986. Fejezetek a magyar katonai repülés történetébõl Budapest: Mûszaki Könyvkiadó.

Oroszi Antal 2015. Adalékok M. Szabó Miklós: Volt egyszer egy egyetem 1996-2007. Rektor a tûzvonalban címû könyvéhez. Hadtudomány 2015 (1-2): 172-183.

Resperger István 2013. Széljegyzet a hatodik (1990-1996) könyvrõl. Honvédségi Szemle 2013 (3): 63-64.

\footnotetext{
${ }^{32}$ M. Szabó 2019, 211-212.

${ }^{33}$ Fekete, M. Szabó 2017, 352-353.
} 
Szabó József, M. Szabó Miklós 2008. A magyar katonai repülés története 1938-2008. Budapest: Zrínyi Kiadó. M. Szabó Miklós 1982. A Magyar Királyi Honvéd Légierõ technikai és szervezeti fejlõdése (1938-1944).

Kandidátusi értekezés. Budapest: Magyar Néphadsereg Vezérkara Tudományos Osztály.

M. Szabó Miklós 1987. A Magyar Királyi Honvéd Légierõ a második világháborúban. Budapest: Zrínyi Kiadó.

M. Szabó Miklós 1999. A Magyar Királyi Honvéd Légierõ elméleti-technikai- szervezeti fejlõdése és háborús alkalmazása 1938-1945. Budapest: Zrínyi Kiadó.

M. Szabó Miklós 2002. az MTA levelezõ tagjának bemutatkozó írása. Magyar Tudomány új folyam 48 (2): 212-213.

M. Szabó Miklós 2004. A magyar katonai felsõoktatás története 1947-1956. Budapest: Zrínyi Kiadó.

M. Szabó Miklós 2007. A Zrínyi Miklós Katonai Akadémia története 1955-1960. Budapest: Zrínyi Kiadó.

M. Szabó Miklós 2008a. Politika - gazdaság - légi fegyverkezés Európában az 1920-30-as években. Budapest: ZMKA.

M. Szabó Miklós 2008b. A Zrínyi Miklós Katonai Akadémia története 1961-1969. Budapest: Zrínyi Kiadó.

M. Szabó Miklós 2010. A Zrínyi Miklós Katonai Akadémia története 1970-1979. Budapest: Zrínyi Kiadó.

M. Szabó Miklós 2011. A Zrínyi Miklós Katonai Akadémia története 1980-1989. Budapest: Zrínyi Kiadó.

M. Szabó Miklós 2014. Volt egyszer egy egyetem 1996-2007 - Rektor a tûzvonalban. Budapest: Zrínyi Kiadó.

M. Szabó Miklós 2017. A Kossuth Lajos Katonai Fõiskola történet (1967-1996) Budapest: Zrínyi Kiadó.

M. Szabó Miklós 2019. A Karikás Frigyes Katonai Kollégium története 1969-1991. Budapest: Zrínyi Kiadó.

M. Szabó Miklós, Oroszi Antal 2012. A Zrínyi Miklós Katonai Akadémia története 1990-1996. Budapest: Zrínyi Kiadó.

Szenes Zoltán 2011. Ötödik könyv: Gondolatok M. Szabó Miklós: A Zrínyi Miklós Katonai Akadémia története 1980-1989 címû könyvérõl. Hadtudomány 21 (4): 134. 